\title{
Rotator manşet yırtıkları
}

\author{
Rotator cuff tears \\ Mahir Mahiroğulları ${ }^{1}$, Mehmet İşyar ${ }^{1}$, Selami Çakmak² \\ ${ }^{1}$ İstanbul Medipol Üniversitesi Tıp Fakültesi, Ortopedi ve Travmatoloji Anabilim Dalı, İstanbul \\ ${ }^{2}$ GATA Haydarpaşa Eğitim Hastanesi, Ortopedi ve Travmatoloji Kliniği, İstanbul
}

\begin{abstract}
Omuz çevresinde özel rotasyonel hareket yapacak tarzda yerleşen rotator manşet kasları yırtıklarının insidansı yaşla birlikte artar. Etiyolojisinde akut veya tekrarlayan kronik travma yer alır. Biseps uzun başı, her ne kadar bu grubun içinde yer almasa da, fonksiyonel olarak rotator manşet içerisindedir ve sıklıkla lezyonları bir arada görülür.
\end{abstract}

Omuz eklemi, sadece koronal ve transvers planda kuvvet çifti dengesi sağlandığında stabil bir hareket dayanağı sağlayabilir. Masif bir rotator manşet yırtığı ile kuvvet çiftlerinin dengesi bozulduğunda, omuz stabil bir destek noktası üretemez ve aktif hareket kaybolur. Bu nedenle rotator manşet yırtığı tamiri kuvvet çiftlerinin dengesinin yeniden oluşturulması için yapılmalıdır.

Ağrı ve fonksiyon kaybı belirginse, yeterli fonksiyonun sağlanması için rotator manşetteki yırtık tamir edilmelidir. Tamir için açık ve artroskopik yöntemler mevcuttur. Açık yöntemler tam açık veya mini açık şeklinde yapılabilir. Artroskopik tamir tecrübe ister, ancak yırtığın net görüntülenmesi için artroskopi daha çok avantaj sağlar. Tamir yöntemleri yırtık tipine, hastaya ve doku kalitesine göre değişim gösterebilir.

Anahtar sözcülkler: omuz; manşon, rotator; artroskopik cerrahi

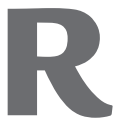

otator manşet kasları ve ekstrinsik omuz kasları omuz çevresinde özel rotasyonel hareket yapacak şekilde yerleşmişlerdir. Kendi içerisinde bir dengesi vardır ve yırtıklarla bu denge bozulur. Omuzda rotator manşet yırtıklarının oluş mekanizması tam olarak ortaya konulmamasına rağmen genel kabul gören teoriler; akut travma sonrası veya kronik tekrarlayıcı travma zemininde yırtık oluşması şeklindedir. ${ }^{[1]}$

Elli yaşla beraber tam kat rotator manşet yırtığı insidansı artış göstermekle birlikte, bu yırtıkların asemptomatik olma insidansları \%22-23 olarak bildirilmiştir. Yırtık insidansı 50 yaştan sonra her bir on yıllık dilimde daha da artmaktadır. ${ }^{[2,3]}$
The incidence of rupture of rotator cuff tendons which are located around shoulder to give it unique rotational movements increases with age. Acute or repetitive trauma plays a role in etiology. Although the tendon of the long head of biceps muscle is not counted in this group, it is functionally included and its lesions are frequently encountered together.

The shoulder joint could only provide a stable fulcrum of movement if there is a balance of force couples in coronal and transvers planes. When this balance of force couples are corrupted by a massive rotator cuff tear, shoulder joint could not function as a fulcrum of motion and subsequently active movement is lost. For this reason, rotator cuff tears must be repaired to re-establish the balance of force couples.

If pain and functional loss is distinctive, rotator cuff rupture should be repaired to provide adequate function. Either open or arthroscopic technique can be used for treatment. In open technique, either full open or mini open procedure can be prefered. Arthroscopic technique needs experience but it is more advantageous than open technique in viewing the rupture. Repairing procedure varies according to rupture type, patient, and tissue quality.

Key words: shoulder; cuff, rotator; arthroscopic surgery

Rotator manşet yırtığı her ne kadar yaşla beraber artsa da gençlerde ve sporcularda da görülebilir, yırtık şekli de kısmi yırtıktan tam kat yırtığa kadar değişiklik gösterebilir. Rotator manşet yırtıklarının kliniği ve tedavisine geçmeden önce kısa bir anatomi bilgisi vermek yerinde olacaktır.

\section{ANATOMI}

Subakromiyal alan, akromiyonun alt yüzeyi, korakoid çıkıntı, akromiyoklavikular eklem, korakoakromiyal ligament arasında kalır. Bu alanda yer alan subakromiyal bursa rotator manşet için kayganlığı

- İletişim adresi: Prof. Dr. Mahir Mahiroğulları, İstanbul Medipol Üniversitesi Tıp Fakültesi, Ortopedi ve Travmatoloji Anabilim Dalı, İstanbul Tel: 0532 - 7791379 e-posta: mahirogullari@gmail.com

- Geliș tarihi: 9 Eylül $2013 \quad$ Kabul tarihi: 25 Ekim 2013 
sağlar. Rotator manşet, glenohumeral eklem için dinamik stabilizatördür. Statik stabilizatörler ise; kapsül ve glenohumeral ligamentleri içerecek şekilde labral komplekstir.

Rotator manşet, humerus başını omuz eklem içerisinde stabilize eden ve deltoid gücüne karşılık yukarıya doğru firlayıp gitmesini engelleyen dört adet kas ve bu kasların tendonlarından oluşur. ${ }^{[4]}$

1- Subskapularis kası: Skapulanın ön yüzünden başlar ve küçük tüberküle yapışır. Subskapular sinir tarafından inerve edilir. Kolun iç rotatuarıdır. Omuz eklemini anterior subluksasyona karşı korur.

2- Supraspinatus kası: Supraspinöz fossadan başlar ve akromiyonun altından glenohumeral eklemi çaprazlayarak büyük tüberküle yapışır. Supraskapular sinir tarafindan inerve edilir. Kola abduksiyon ve dış rotasyon yaptırır. Asıl önemli rolü, abduksiyon sırasında humerus başının aşağı doğru kaymasına engel olmaktır.

3- İnfraspinatus kası: İnfraspinöz fossadan başlar ve supraspinatus gibi omuz eklemini çaprazlayarak, hemen onun posteriorunda büyük tüberküle yapışır. Yapışma yerlerinin $15 \mathrm{~mm}$ proksimalinde supraspinatus ve infraspinatus birleşirler. Kola dış rotasyon yaptırır. Supraskapular sinir tarafindan inerve edilir.

4- Teres minör kası: Skapulanın dış kenarından başlar, humerus başı arkasından büyük tüberküle yapışır. Genellikle infraspinatusa yapışıkır. Aksiller sinir tarafından inerve edilir. Kola dış rotasyon yaptırır.

Biseps tendonu uzun başı, rotator manşetin bir üyesi olmamakla birlikte, fonksiyonel olarak bu grubun içinde yer alır. Rotator manşet yırtıklarına genellikle biseps uzun başı lezyonları da eşlik eder. İki başlıdır. Uzun başı supraglenoid tuberkül ve labrumdan, kısa başı korakoid çıkıntıdan başlar, distalde radius üzerinde radial tüberküle yapışır. Biseps uzun başı humerusun statik depresörüdür. Ön kol sabitken kola fleksiyon da yaptırır. Muskulokutanöz sinir tarafından inerve edilir. Subskapularis tendonu ve korakohumeral ligament dejenerasyonunda veya rüptürlerinde biseps uzun başı mediale lukse olur.

\section{BIYOMEKANIK}

Etki yönleri cismin kütle merkezinden geçmeyen şiddetleri eşit ve yönleri zıt iki kuvvet bir cisme etki ederlerse, bu kuvvetlerin oluşturduğu ikiliye kuvvet çifti denir. Omuz eklemi, sadece koronal ve transvers planda kuvvet çifti dengesi sağlandığında stabil bir hareket

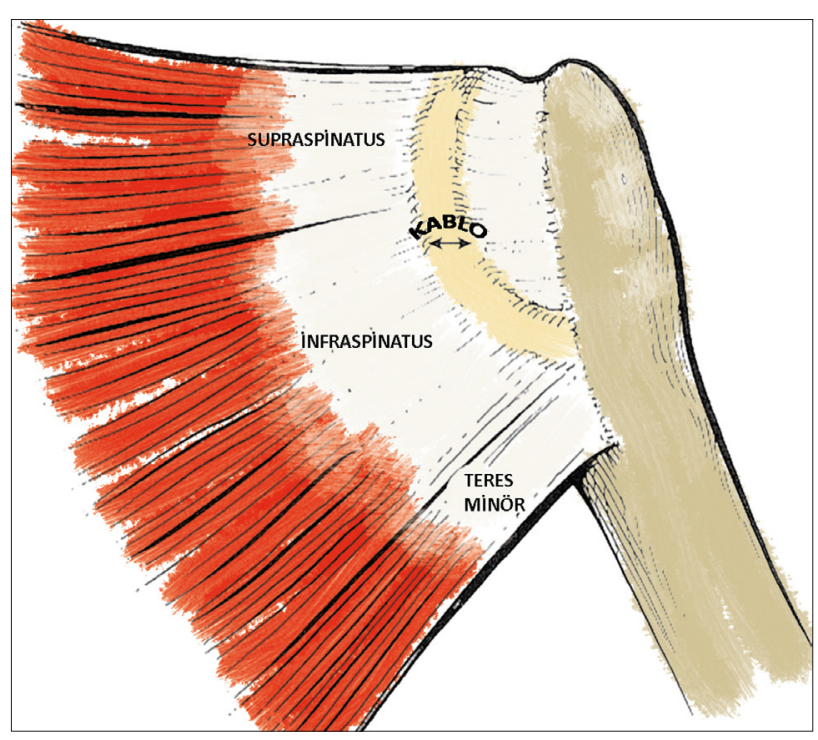

Şekil 1. Süspansiyon köprüsü.

dayanağı sağlayabilir. ${ }^{[5]}$ Koronal planda manşet deltoide karşı dengelemeyi, transvers planda ise önden subskapularis, arkada infraspinatus ve teres minöre karşı dengelemeyi sağlar. Masif bir rotator manşet yırtığı ile kuvvet çiftlerinin dengesi bozulduğunda, omuz stabil bir destek noktası üretemez ve aktif hareket kaybolur. Bu nedenle, kuvvet çiftlerinin dengesinin yeniden oluşturulması için rotator manşet yırtığı tamiri yapılmalıdır. ${ }^{[5]}$

Hem anatomik hem de biyomekanik açıdan bir diğer önemli oluşum kablo-hilal kompleksidir. ${ }^{[6]}$ Rotator manşeti oluşturan kaslar büyük tüberküle doğru uzanırken tendon halini almadan önce bir kablo şeklinde uzanır, daha sonra tendonlar hilal tarzında bir yapı oluşturarak incelir ve büyük tüberkülün üzerini örter. Kablo-hilalin etrafını kalın bir doku olarak sarar. Kablo yük taşıyan süspansiyon köprüsü gibi davranır (Şekil $1)$. Yükü, avaskuler ince hilal yapıya aktarırken azaltmış olur. ${ }^{[7]}$

\section{TANI}

Rotator manşet yırtığında hasta geliş nedeni sıklıkla ağrıdır. Ağrının yeri ve yayılımı mutlaka sorgulanmalı, hastanın ağrının yerini göstermesi istenmelidir. Servikal problemlerin omuza yansıyacağı akılda tutularak boyun muayenesi yapılmalıdır. Ardından gözle deltoid ve rotator manşet kasları izdüşümlerinde atrofisi, şişme, subluksasyon gibi durumların var olup olmadığı izlenmelidir. Palpasyonla ağrı tam lokalize edilmeye çaIsşılmalıdır. Ayırıcı tanı için bu lokalizasyon önemlidir. Hastanın ağrısını provoke etme yöntemiyle çalışan bir 
Tablo 1. Rotator manşet yırtıkları için testler

\begin{tabular}{|c|c|c|}
\hline Kas & Test & Pozitif bulgu \\
\hline Supraspinatus & Düşük kol testi (Drop Arm) & $\begin{array}{l}\text { Muayene eden kişi, hastanın kolunu } 90^{\circ} \text { elevasyona getirir; hasta bu } \\
\text { pozisyonu muhafaza edemez }\end{array}$ \\
\hline İnfraspinatus & Eksternal rotasyon yetersizliği testi & $\begin{array}{l}\text { Muayene eden kişi, hastanın kolunu adduksiyonda iken maksimum eksternal } \\
\text { rotasyona getirir; hasta bu pozisyonu muhafaza edemez }\end{array}$ \\
\hline Teres minör & Borazancı (Hornblower) bulgusu & $\begin{array}{l}\text { Muayene eden kişi, hastanın kolunu } 90^{\circ} \text { abduksiyona, } 90^{\circ} \text { eksternal } \\
\text { rotasyona getirir; hasta bu pozisyonu muhafaza edemez }\end{array}$ \\
\hline Üst subscapularis & Göbeğe bastırma testi & $\begin{array}{l}\text { Hasta ellerini abdomen üzerine getirir ve dirseklerini vücudun midsagital } \\
\text { hattının önündeki pozisyonda muhafaza edebilmelidir }\end{array}$ \\
\hline Alt subscapularis & Yukarı kaldırma (Lift Off) testi & $\begin{array}{l}\text { Muayene eden kişi, hastanın ellerini lumbosakral vertebradan uzaklaştırmaya } \\
\text { çalışır; hasta ellerinin pozisyonunu muhafaza edemez }\end{array}$ \\
\hline
\end{tabular}

takım manevraları içeren muayene testleri yapılmalı ve omuz hareket genişliği değerlendirilmelidir. Testler çok çeşitlidir ve her bir tendon ve yapı için tanımlanmış testler mevcuttur. Bunlar farklı kaynaklardan takip edilebilir. Burada en önemli nokta, anahtar testleri defalarca yapmak ve hastanın ağrı duyma derecesi ve kolunu kaldırma gücünün ölçülmesi için yeterli tecrübeyi kazanmaktır. Ne kadar çok hasta muayene edilirse ve aynı testler uygulanırsa cerrahın belirli bir kavrama seviyesi o kadar yükselecek ve tedavi kararını daha sağlıklı verebilecektir. Burada belli başlı testlerin nasıl yapıldığı ve hangi tendona yönelik yapıldığı tabloda verilmiştir (Tablo 1). Testleri karşı taraf ile karşılaştırmalı yapmak önemlidir.

\section{GÖRÜNTÜLEME}

Konvansiyonel röntgen rotator manşet yırtıklarının tanısında oldukça yardımcıdır; ayırıcı tanı için de gereklidir. Ön arka omuz grafisi (iç ve dış rotasyonda alınırsa daha yardımcı olur), skapula $\mathrm{Y}$ grafisi veya supraspinat çıkış grafisi, lateral aksiller grafi alınabilecek diğer grafilerdir. Bu grafilerde tuberkulum majusta skleroz olması, subakromial alanda çıkıntı olması, akromiohumeral eklem mesafesinde azalma, manşet yırtığını akla getirmelidir. Bu grafiler iyi bir muayene ile eşleştirilirse doğru tanıya çok yaklaşılabilir.

Ultrasonografi aslında ucuz, noninvazif bir yöntemdir ve tecrübeli ellerde oldukça faydalı olabilmektedir. Ancak, eşlik eden patolojilerin ortaya konulmasında tam bir standardizasyon yapılamaması ve kişisel tecrübeye dayanması kullanışııı̆ını azaltmaktadır.

Manyetik rezonans (MR) günümüzde en sık kullanılan tanı yöntemidir. Hem tanıda hem de tedavi sonrası beklentileri tayin etmede oldukça sık başvurulan bir yöntemdir. Tek tek tendonları ortaya koyabildiği gibi, tendonun ne kadar geriye kaçtığını, yağlı dejenerasyona uğrayıp uğramadığını MR sayesinde görebiliriz. Artro MR yapıldığında daha küçük ve kısmi yırtıkların tespiti daha kolay hale gelebilir. Buradaki önemli nokta, ameliyatı yapacak olan ortopedik cerrahın patolojiyi derinliğine görebilecek derecede MR okumayı biliyor olmasıdır ki, cerrahi endikasyonunu ve planını buna göre yapabilsin.

Bilgisayarlı tomografi (BT) ise daha ziyade manşet yırtığı artropatisinde kemik kaybının derecesini görme açısından kullanışlıdır. Ayrıca rotator manşet kasları yağlı dejenerasyonunu ortaya koyan Goutallier sınıflandırması BT temelli bir sınıflandırmadır (Tablo 2). Bu sınıflandırma sayesinde yırtığın tamir edilip edilemeyeceği değerlendirilebilir.

\section{SINIFLANDIRMA}

Aslında yaygın kullanılan tek bir sınıflandırma yoktur. Ayrıca sınıflandırmayı yırtığın derinliğine, etiyolojisine, oluş zamanına, büyüklügüne, şekline, eşlik eden tendon sayısına, yırtığın yerleşimine ve tendonun kalitesine göre yapabiliriz. Çok parametreli ve çok boyutlu bir patoloji olduğu için, sınıflandırmalar da çeşitlilik gösterecektir. Biz burada nispeten daha detaylı ve

Tablo 2. Yağ infiltrasyonu için Goutallier sınıflandırması

\begin{tabular}{ll}
\hline Grade & Bulgu \\
\hline 0 & Kas içerisinde yağ yok \\
1 & Yer yer yağ çizgilenmeleri \\
2 & Yağ $<$ kas \\
3 & Yağ $=$ kas \\
4 & Yă̆ $>$ kas
\end{tabular}


Tablo 3. Rotator manşet yırtıklarının Patte sınıflaması

\section{Yırtığın derecesi}

Grup I: Kısmi yırtıklar ya da kemikten ayrışımındaki sagital planda 1 cm'den küçük olan tüm-cisim yırtıkları
a. Derin, parsiyel yırtıklar
b. Yüzeyel yırtıklar
c. Küçük, tüm-cisim yırtıkları

Grup II: Supraspinatusun tamamının tüm-cisim yırtıkları

Grup III: Birden çok tendonu içeren tüm-cisim yırtıkları

Grup IV: Sekonder osteoartritle birlikte masif yırtık

Yırtığın sagittal plandaki topografisi

Segment I: Subscapular yırtık

Segment II: Coracohumeral ligament yırtığ

Segment III: İzole supraspinatus yırtığı

Segment IV: Supraspinatusun tamamı ve infraspinatusun yarısının yırtığı

Segment V: Supraspinatus ve infraspinatusun yırtı̆̆

Segment VI: Subscapularis, supraspinatus ve infraspinatusun yırtığı

Yırtığın frontal plandaki topografisi

Seviye I: Insersiyoda proksimal güdük

Seviye II: Caput humeri seviyesinde proksimal güdük

Seviye III: Glenoid seviyesinde proksimal güdük

Kasın kalitesi
1. Minimal yağ katmanı
2. Kastan az yăg
3. Kas ve yağ eşit
4. Kastan çok yağ

Biceps tendonunun durumu
1. Sağlam
2. Sublükse
3. Çıkık (Disloke)

daha çok parametreyi içine alan Patte sınıflandırmasını vereceğiz (Tablo 3 , Şekil 2). Yine cerrahi manevraları belirleme ve yırtık tiplerinin anlaşılabilmesi açısından yırtığın şekline göre yapılan sınıflandırma da Şekil 3'te gösterilmiştir.

\section{TEDAVi}

Rotator manşet yırtıklarının tedavisinin seçiminde konservatif ve cerrahi yöntemler yer alır. Özellikle semptomların az olduğu ve nispeten daha küçük yırtıklarda tedavi yöntemi tartışması halen devam etmektedir. Tam kat yırtıklarda cerrahi tedavi yaygın olarak seçilmekte birlikte, konservatif tedavi ile başarılı sonuçlar alındığını bildiren çalışmalar mevcuttur. ${ }^{\left[{ }^{[8,9]}\right.}$ Hastanın yaşına, yırtığın boyutuna ve yırtık bölgesindeki atrofinin derecesine bağlı olmakla birlikte, tedavi yöntemleri arasında konservatif tedavi de yerini almıştır. ${ }^{[3,10]}$ Ancak, henüz tam olarak görüş birliğine varılmış bir rehabilitasyon yöntemi veya egzersiz akış seması yoktur. Konservatif tedavide temeli, kişinin günlük yaşam aktivitelerini kolaylaştırmaya yönelik uğraşı terapileri, kas gücünün ve eklem hareket açıklığının geliştirilmesine yönelik egzersiz programları oluşturmaktadır. ${ }^{[10]}$ Atravmatik tam kat rotator manşet yırtığı olan hastaların dahil edildiği çok merkezli bir çalışmada, fizik tedavi aşamasında hastalardaki ağrı ve fonksiyon kaybı ile ilişkili olabilecek bir takım faktörlerin hedeflenmesi gerektiği belirtilmiş ve skapulotorasik diskinezi, kolun öne elevasyonu ile aktif abduksiyonun üzerinde çalışıması yöntemiyle konservatif olarak başarılı sonuçlar alınabileceği bildirilmiştir. ${ }^{[11]}$ Konservatif tedaviye rağmen yırtıkta zaman içinde iyileşme görülmemesi, bilinen semptomlara ağrı ve hareket kaybının da eklenmeye başlaması, konservatif tedaviden artık uzaklaşmak gerektiğine işaret eder.

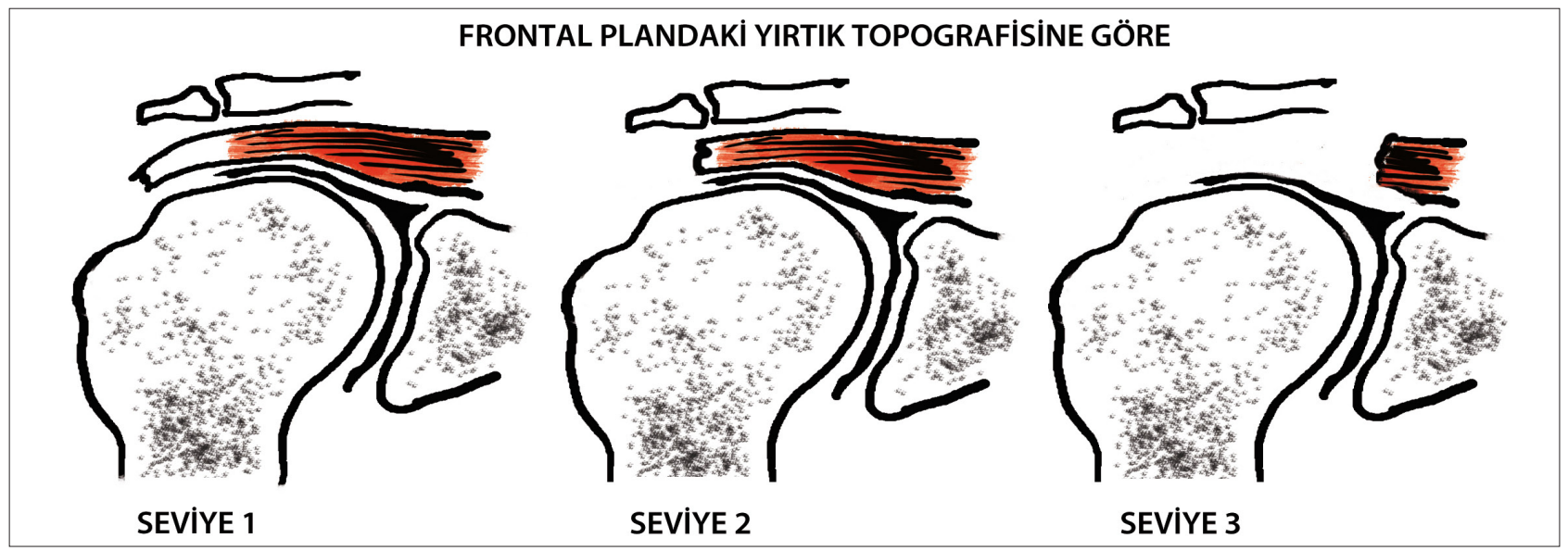

Şekil 2. Patte sınıflandırması. 

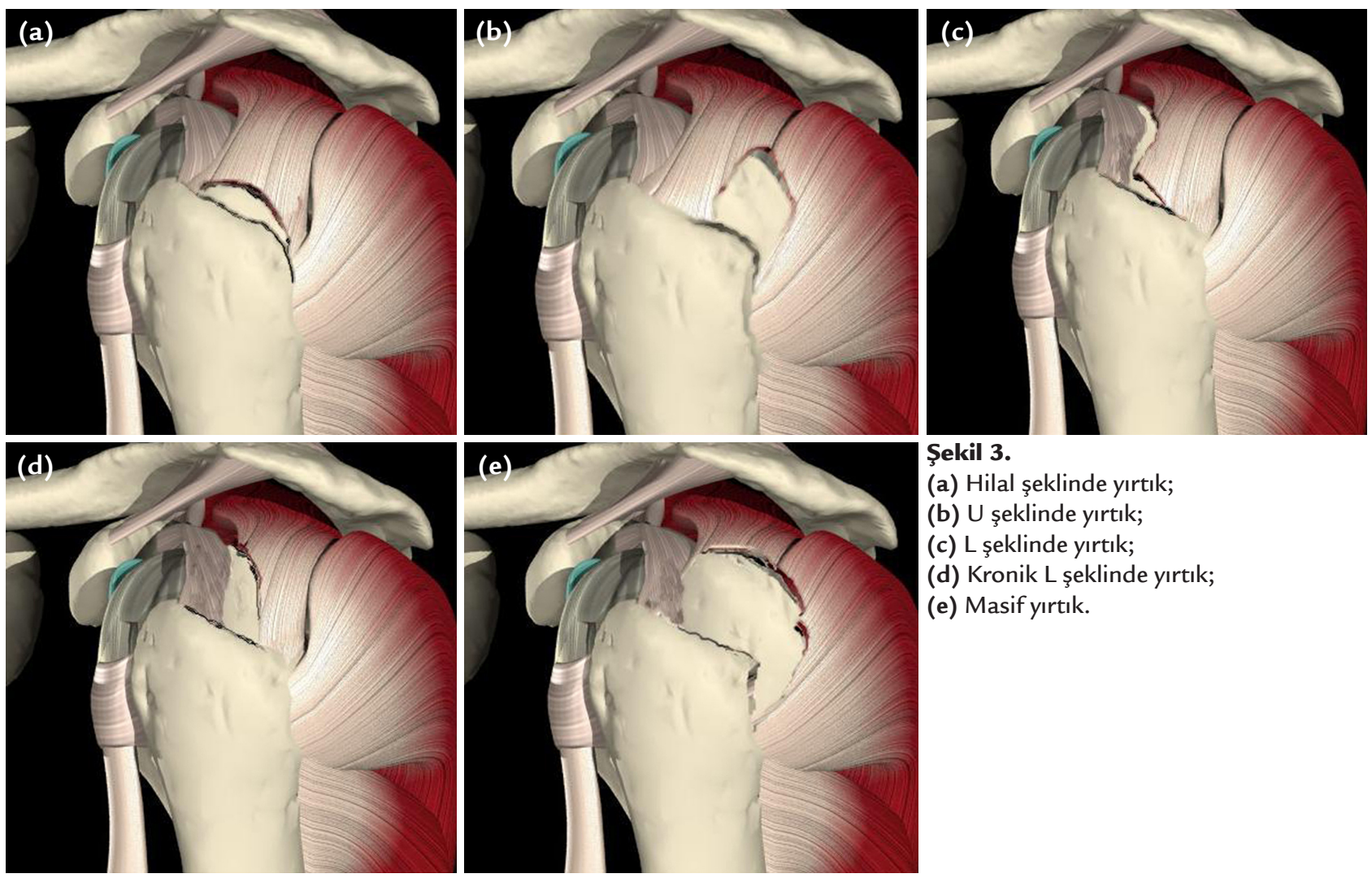

Şekil 3.

(a) Hilal şeklinde yırtık;

(b) U şeklinde yırtık;

(c) L şeklinde yırtık;

(d) Kronik L şeklinde yırtık;

(e) Masif yırtık.

Cerrahi tedavinin nasıl olacağını belirlemeden önce, tedavide nelerin gerektiğini bilmek gerekir. Yeterli fonksiyonun sağlanması için, rotator manşetteki yırtığın tam anatomik tamiri gerekli değildir ve tam anatomik tamir teknik olarak mümkün de değildir. Yırtık kenarlarının fibrotik ve avasküler hale gelmiş olması nedeniyle tamir sahasında vasküler bir kemik yatağının hazırlanması ve yırtık kenarlarının tazelenmesi gereklidir. Yırtığın mediale doğru supraspinat kas, öne doğru subskapular kas ve arkaya doğru infraspinat kas tarafından çekilmekte olduğu düşünüldüğünde, tamir bittiğinde kol vücudun yanında iken (yani abduksiyonda değilken) tamir sahasının gergin olmaması gerekir. Gerginlik olmadan yırtık kenarlarının uç uca getirilerek tamiri ve son olarak hazırlanan kemik yatağına sabitlenmesi ile rotator kaslar arasındaki devamlılık sağlanmış olur. Tamir sahasının akromiyon ile temasta olacağı üst yüzeyinin düzgün olması da önemlidir. Ekleme hareket verilmesi ile eklem sıvısının pompalanmasının etkisiyle sıvının subakromiyal bölgeye geçmesi tamiri tehlikeye atacağından, tamirin sıkıca yapılması önemlidir. Böylelikle tamir sonrasında yeni bir yırtık oluşması da önlenmiş olur. ${ }^{[12]}$

Son yıllarda rotator manşet yırtıklarını tamir etmek için artroskopik yöntemlerin kullanımı giderek artmaktadır. Rotator manşet yırtıklarının tedavisine karar vermeden önce bölgesel anatomi ve biyomekaniğin de iyi anlaşılması gerekmektedir. Uygun tedavi yöntemi ancak bu şekilde seçilebilir. Sadece yırtık alanın kapatılması şeklindeki basit ve geleneksel fakat uygun olmayan tedavi yöntemleri basarısızlıkla sonuçlanabilir. Rotator manşet kasları ve omuz çevresi kaslarının eşgüdümü ile omuza özel rotasyon hareketleri sağlanır. Dahası, omuzun stabil bir şekilde hareketinin sağlanabilmesi için, koronal ve transvers düzlemde kuvvet çifti dengesinin sağlanması gereklidir. ${ }^{[13]}$

Artroskopik olarak rotator manşet yırtıklarının tedavisinde, öncelikle ideal görüntü için, omuz artroskopisinin uygun giriş noktalarından ve uygun biçimde yapılması gerekir. Yırtığa ulaşmak için portal giriş yerleri ve alternatifleri bilinmelidir. Açık tamir, anterior yaklaşımla yapılır. Açık cerrahide cerrahın yırtığı görüş alanı içine alması gerekir ki, uygun görüş ve tamir bu kısıtIı alanda zordur. Artroskopi ile yırtık bölgeye ulaşım daha kolaydır; farklı açılardan yırtık olan bölgeye ulaşılıp detaylı muayene edilebilir ve tamir de yapılabilir. Yırtığın $360^{\circ}$ olarak ortaya konulması ve tiplendirilerek uygun tedavinin yapılması artroskopi ile sağlanabilir. Hilal şeklindeki yırtıklar klasik yırtıklardır ve mediallateral doğrultuda ve farklı uzunluktadır. Bu yırtıklar 
doğrudan kemiğe tespit ile tamir edilebilir. U şekilli yırtıklar daha mediale uzanır ve yırtığın en medial kısmı glenoid hizasına uzanabilir. Bu yırtık şeklini anlamak önemlidir çünkü yırtığı medialde mobilize edip yırtığın en medial kısmını lateral kemik yatağına kadar çekerek tamir etmek aşırı gerginliğe neden olur, sonrasında da başarısız bir tamirle sonuçlanır. Medialden başlayıp laterale doğru giderek ön ve arka yırtık kenarlarının dikilmesi daha uygundur. Böylece, en lateralde yırtığın serbest kenarı gerginlik olmadan kemik yatağına tamir edilebilir. L şekilli yırtıklar $U$ şekilli yırtıklara benzer; ancak $L$ şekilli yırtıklarda bir kenar daha mobildir ve kemik tamir yatağına veya diğer kenarın yanına daha kolay getirilebilir. L şekilli yırtıkta, yine longitudinal yırtık uç uca dikilir ve en son serbest lateral kenar kemiğe sabitlenir. Bu üç tip yırtık, postero-superior rotator manşet yırtıklarının \%90'ını oluşturur.

Tedavi sonrasında tamirin korunması ve tekrar yırtık oluşmasının engellenmesi amacıyla yapılan çalışmalar sonucunda, dikiş teknikleri ve dikiş materyallerinde gelişmeler sağlanmış ve tekrar yırtık oluşma riski \%912'lere kadar azalmıştır.

Artroskopik tedavide ilk baştan bu yana kullanılmakta olan ve standart dikiş yöntemi halini alan tek sıra dikiş tamir yönteminde başarılı sonuçlar bildirilmiştir. ${ }^{[14]}$ Ancak, hasta memnuniyeti iyi olmasına rağmen, tekrar yırtılma riskinin fazla olduğunun gösterilmesi ve tendonun anatomik yapışma yerinin tam kapatılamıyor olması gibi nedenlerden dolayı, çift sıra dikiş tamir yöntemi ortaya çıkmıştır. ${ }^{[15]}$ Burada hedef, tamir edilen tendon yüzeyinin daha çok kemik yüzeyi ile karşı karşıya gelmesi ve böylelikle daha hızlı ve daha güçlü bir iyileşmedir. Her ne kadar kadavra çalışmalarında çift sıra dikiş yönteminin biyomekanik olarak daha güçlü olduğu gösterilmişse de, klinikte fonksiyonel açıdan tek sıra dikiş yöntemi ile arasında anlamlı bir farklılık bulunamamıştır. ${ }^{[16,17]}$

Tamire destek amacıyla, bir takım biyolojik destek tedavileri de kullanılmaktadır. Rotator manşet tamirinde, 1500 'den fazla biyoaktif protein içerdiği bilinen ve tendon iyileşmesinde rol alan birçok büyüme faktörünü içinde barındıran trombositten zengin plazma (TZP) kullanılmaktadır. Yapılan birçok çalışmada TZP'nin tamirde rol aldığı bildirilmiş olsa da, tamir mekanizması ve sonuçlarının homojenliği konusundaki tartışmalar devam etmektedir. Yapılan çalışmalarda TZP hazırlanma yöntemleri, dozajı ve uygulama şekillerinin farklı olması, çalışmaların aynı platformda karşılaştırılma şansını azaltmaktadır. ${ }^{[18,19]}$

Sonuç olarak, rotator manşet yırtıkları, ileri yaş aktiviteleri arttıkça ve insan ömrü uzadıkça ortopedik cerrahların karşııına daha sıklıkla çıkmaktadır. Gerçek patolojiyi ortaya koyup, uygun tedaviyi gerek cerrahi gerekse konservatif olarak planlayarak yapmak ve ardından uygun rehabilitasyon protokollerini vermek tedavinin anahatlarıdır. İyi tedavi edilmiş bir manşet yırtığının klinik sonuçları oldukça yüz güldürücü olacaktır. Burada önemli nokta, cerrahın işini en iyi bildiği yöntemle yapmasıdır. Ancak artroskopinin sağladığı geniş görüş açısını ve daha hızlı rehabilitasyonu gözardı etmemek gerekir.

\section{KAYNAKLAR}

1. Getz CL, Buzzell JE, Krishnan SG. Shoulder Instability and Rotator CuffTears. Flynn JM, editor. Orthopaedic Knowledge Update 10. Rosemont: American Academy of Orthopaedic Surgeons; 2011. p. 299-315.

2. Tempelhof S, Rupp S, Seil R. Age-related prevalence of rotator cuff tears in asymptomatic shoulders. J Shoulder Elbow Surg 1999;8(4):296-9.

3. Yamaguchi K, Ditsios K, Middleton WD, Hildebolt CF, Galatz LM, Teefey SA. The demographic and morphological features of rotator cuff disease. A comparison of asymptomatic and symptomatic shoulders. J Bone Joint Surg Am 2006;88(8):1699-704.

4. Crusher RH. Rotator cuff injuries. Accid Emerg Nurs 2000;8(3):129-33.

5. Burkhart SS. Arthroscopic treatment of massive rotator cuff tears. Clinical results and biomechanical rationale. Clin Orthop Relat Res 1991;(267):45-56.

6. Burkhart SS, Esch JC, Jolson RC. The rotator crescent and rotator cable: an anatomic description of the shoulder's "suspension bridge". Arthroscopy 1993;9(6):611-6.

7. Halder AM, O'Driscoll SW, Heers G, Mura N, Zobitz ME, An $\mathrm{KN}$, Kreusch-Brinker R. Biomechanical comparison of effects of supraspinatus tendon detachments, tendon defects, and muscle retractions. J Bone Joint Surg Am 2002;84-A(5):780-5.

8. Kijima $H$, Minagawa $H$, Nishi T, Kikuchi $K$, Shimada $Y$. Long-term follow-up of cases of rotator cuff tear treated conservatively. J Shoulder Elbow Surg 2012;21(4):491-4. CrossRef

9. Maman E, Harris C, White L, Tomlinson G, Shashank $M$, Boynton E. Outcome of nonoperative treatment of symptomatic rotator cuff tears monitored by magnetic resonance imaging. J Bone Joint Surg Am 2009;91(8):1898906. CrossRef

10. Krischak G, Gebhard F, Reichel H, Friemert B, Schneider F, Fisser C, Kaluscha R, Kraus M. A prospective randomized controlled trial comparing occupational therapy with homebased exercises in conservative treatment of rotator cuff tears. J Shoulder Elbow Surg 2013;22(9):1173-9. CrossRef

11. Harris JD, Pedroza A, Jones GL; MOON (Multicenter Orthopedic Outcomes Network) Shoulder Group. Predictors of pain and function in patients with symptomatic, atraumatic full-thickness rotator cuff tears: a time-zero analysis of a prospective patient cohort enrolled in a structured physical therapy program. Am J Sports Med 2012;40(2):359-66. CrossRef

12. McLaughlin HL. Rupture of the rotator cuff. J Bone Joint Surg Am 1962;44-A:979-83.

13. Burkhart SS, Lo IK. Arthroscopic rotator cuff repair. J Am Acad Orthop Surg 2006;14(6):333-46. 
14. Galatz LM, Ball CM, Teefey SA, Middleton WD, Yamaguchi K. The outcome and repair integrity of completely arthroscopically repaired large and massive rotator cuff tears. J Bone Joint Surg Am 2004;86-A(2):219-24.

15. Chen M, Xu W, Dong Q, Huang Q, Xie Z, Mao Y. Outcomes of single-row versus double-row arthroscopic rotator cuff repair: a systematic review and meta-analysis of current evidence. Arthroscopy 2013;29(8):1437-49. CrossRef

16. Kim DH, Elattrache NS, Tibone JE, Jun BJ, DeLaMora SN, Kvitne RS, Lee TQ. Biomechanical comparison of a single-row versus double-row suture anchor technique for rotator cuff repair. Am J Sports Med 2006;34(3):407-14.
17. ParkJY, Lhee SH, Choi JH, Park HK, YuJW, Seo JB. Comparison of the clinical outcomes of single- and double-row repairs in rotator cuff tears. Am J Sports Med 2008;36(7):1310-6. CrossRef

18. Barber FA, Hrnack SA, Snyder SJ, Hapa O. Rotator cuff repair healing influenced by platelet-rich plasma construct augmentation. Arthroscopy 2011;27(8):1029-35. CrossRef

19. Jo CH, Shin JS, Lee YG, Shin WH, Kim H, Lee SY, Yoon KS, Shin S. Platelet-Rich Plasma for Arthroscopic Repair of Large to Massive Rotator Cuff Tears: A Randomized, Single-Blind, Parallel-Group Trial. Am J Sports Med 2013. [Epub ahead of print] 